\title{
PENGARUH PENGGUNAAN DISCOVERY LEARNING DENGAN SCRAMBLE TERHADAP KEAKTIFAN BELAJAR DAN HASIL BELAJAR MATEMATIKA SISWA KELAS X SMA N 1 KLEGO KABUPATEN BOYOLALI SEMESTER II TAHUN PELAJARAN 2020 / 2021
}

\author{
DESIE NARMIA SARI \\ SMA N 1 Klego Kabupaten Boyolali \\ Email: Desie.narmia@gmail.com
}

\begin{abstract}
ABSTRAK
Penelitian ini bertujuan untuk mengetahui ada tidaknya pengaruh penggunaan discovery learning dengan scramble terhadap keaktifan belajar dan hasil belajar matematika siswa kelas X SMA N 1 Klego Kabupaten Boyolali Semester II Tahun Pelajaran 2020/2021. Populasi dalam penelitian ini adalah semua siswa kelas X SMA N 1 Klego Kabupaten Boyolali yang berjumlah 203 siswa yang terbagi dalam 6 kelas. Teknik pengambilan sampel dengan cluster random sampling dan diperoleh kelas X IPS 1 sebagai kelas eksperimen (36 siswa) dan kelas X IPS 2 sebagai kelas kontrol (33 siswa). Desain penelitian ini adalah the randomized kontrol group pretest posttest design. Uji keseimbangan kondisi awal untuk keaktifan belajar dan hasil belajar berturut-turut menghasilkan nilai signifikansi sebesar 0,070 dan 0,978, keduanya lebih dari 0,05. Artinya kedua kelompok sampel dalam kondisi seimbang baik untuk keaktifan belajar maupun hasil belajar. Adapun hasil uji hipotesis keaktifan belajar menghasilkan nilai signifikansi sebesar 0,01 dengan rata-rata keaktifan belajar kelas eksperimen 80,11 lebih baik dari kelas kontrol 76,03. Sedangkan hasil uji hipotesis hasil belajar menghasilkan nilai signifikansi 0,023 dengan rata-rata hasil belajar kelas eksperimen 69,72 lebih baik daripada kelas kontrol 65,39. Masing-masing nilai signifikansi kurang dari 0,05 sehingga dapat disimpulkan bahwa terdapat pengaruh penggunaan discovery learning dengan scramble baik terhadap keaktifan belajar ataupun hasil belajar matematika siswa kelas X SMA N 1 Klego Kabupaten Boyolali.
\end{abstract}

Kata Kunci : Model Pembelajaran, Discovery Learning, Scramble, Belajar Matematika

\section{PENDAHULUAN}

Matematika merupakan salah satu mata pelajaran yang harus dikuasai siswa baik pada pendidikan formal maupun non formal. Salah satu tujuan pembelajaran matematika menurut Permendiknas No. 22 Tahun 2006 tentang Standar Isi Mata Pelajaran Matematika yaitu agar para siswa SMA memahami konsep matematika, menjelaskan keterkaitan antar konsep, dan mengaplikasikan konsep atau algoritma secara luwes, akurat, efisien, dan tepat dalam pemecahan masalah. Keberhasilan pembelajaran salah satunya dapat dilihat dari hasil belajar. Meskipun demikian, hasil belajar masih menjadi permasalahan dalam pembelajaran matematika. Menurut Sudjana (2009:22), hasil belajar adalah kemampuan yang dimiliki siswa setelah menerima pengalaman belajar. Sejalan dengan hal tersebut, menurut Nasution (2006: 36), hasil belajar adalah hasil dari suatu interaksi tindak belajar mengajar dan biasanya ditunjukkan dengan nilai tes yang diberikan oleh guru baik tes tertulis maupun non tes. Berdasarkan pengertian tersebut, dapat disimpulkan bahwa hasil belajar matematika adalah kemampuan yang dimiliki siswa sebagai salah satu wujud interaksi adanya kegiatan pembelajaran yang ditunjukkan dengan nilai tes.

Selain dari hasil belajar, kunci keberhasilan pencapaian tujuan pembelajaran juga terletak pada keaktifan belajar siswa dalam proses pembelajaran (Rusman, 2013:111). Gulo (2010:23) mengungkapkan bahwa pembelajaran menjadikan siswa sebagai subyek yang aktif dalam proses pembelajaran dan bukan lagi obyek pembelajaran. Hamalik (2008: 65) menyatakan bahwa pembelajaran menekankan pada keaktifan siswa dalam proses pembelajaran. 
Tujuan pembelajaran matematika menurut permendiknas menyatakan agar siswa memahami konsep dengan benar, namun hasil penelitian yang telah dilakukan oleh Sepdoni (Pika,2014) menyatakan bahwa dalam proses pembelajaran siswa sering terjebak dalam penggunaan konsep dan kebanyakan siswa hanya menerima dan menghafal konsep dan rumus tanpa mengetahui makna dari rumus tersebut, sehingga siswa tidak memahami dan mampu menggunakan konsep dengan baik dan sesuai. Bruner (Hudojo,1990:49) menambahkan bahwa belajar matematika ialah belajar tentang konsep-konsep dan struktur matematika yang terdapat di dalam materi yang dipelajari serta mencari hubungan-hubungan antar konsepkonsep dan struktur matematika, sehingga dapat dikatakan bahwa matematika merupakan bahasa simbol dengan beberapa istilah yang telah disepakati sebagai alat komunikasi yang bersifat terstruktur, deduktif, sistematis dan konsisten serta merupakan kumpulan sistem yang memiliki objek tujuan abstrak.

Berdasarkan permasalahan hasil belajar siswa juga terdapat teori keaktifan belajar, serta adanya hasil penelitian yang menyatakan bahwa siswa sering terjebak dalam penggunaan konsep matematika tanpa mengetahui makna dari rumus tersebut. Untuk itu model pembelajaran harus dirancang dengan baik agar kegiatan pembelajaran dapat memberikan hasil belajar yang diharapkan (Rusman, 2013: 379). Salah satu model pembelajaran yang dapat mengaktifkan dan membangun pengetahuan siswa dengan cara mengkonstruksikan pengetahuan yang dimiliki siswa yaitu model discovery learning.

Model Discovery Learning lebih menekankan pada ditemukannya konsep atau prinsip yang sebelumnya tidak diketahui oleh siswa. Menurut Bruner perkembangan kognitif ditandai dengan kecakapan mengemukakan beberapa alternative secara stimulus, memilih tindakan yang tepat, membuat kesimpulan, mengerti dan sebagainya. Lebih lanjut, Bruner (Budiningsih, 2005: 41) mengatakan bahwa discovery learning adalah proses belajar yang memberikan kesempatan kepada siswa untuk menemukan suatu konsep, teori, aturan atau pemahaman melalui contoh-contoh yang dapat dijumpai dalam kehidupan sehari-hari. Adapun tahapan pelaksanaan discovery learning (Kemendikbud, 2013) yaitu tahap stimulation (pemberian rangsangan sebelum pembelajaran dimulai yaitu siswa dihadapkan pada sesuatu yang menimbulkan kebingungannya, kemudian dilanjutkan untuk tidak memberi generalisasi, agar timbul keinginan untuk menyelidiki sendiri serta dapat mengembangkan dan membantu siswa dalam mengeksplorasi bahan), tahap problem statement (identifikasi masalah yaitu guru memberi kesempatan kepada siswa untuk mengidentifikasi sebanyak mungkin masalah yang relevan dengan bahan pelajaran, kemudian salah satunya dipilih), tahap data collection (pengumpulan data yaitu guru juga memberi kesempatan kepada siswa untuk mengumpulkan informasi sebanyak-banyaknya yang relevan untuk membuktikan benar atau tidaknya hipotesis), tahap data processing (pengolahan data yaitu kegiatan mengolah data dan informasi yang telah diperoleh siswa baik melalui wawancara, observasi, dan sebagainya, lalu ditafsirkan), tahap verification (pembuktian yaitu siswa melakukan pemeriksaan secara cermat untuk membuktikan benar atau tidaknya hipotesis yang ditetapkan dengan temuan alternatif, dihubungkan dengan hasil data processing), dan tahap generalization (menarik kesimpulan yaitu proses menarik sebuah kesimpulan yang dapat dijadikan prinsip umum dan berlaku untuk semua kejadian atau masalah yang sama, dengan memperhatikan hasil verifikasi).

Terdapat penelitian yang menunjukkan bahwa model discovery learning mempunyai pengaruh yang signifikan terhadap hasil belajar matematika siswa diantaranya penelitian yang dilakukan oleh Arinawati (2014) yang berjudul "pengaruh model pembelajaran discovery learning terhadap hasil belajar matematika ditinjau dari motivasi belajar." Akan tetapi terdapat penelitian yang menunjukkan bahwa model discovery learning tidak berpengaruh terhadap hasil belajar, namun berpengaruh terhadap keaktifan belajar siswa pada materi ekosistem diantaranya penelitian yang dilakukan oleh Rosilla (2012) yang berjudul "pengaruh model discovery learning dengan metode praktikum pada materi ekosistem terhadap keaktifan dan hasil belajar siswa kelas X MAN Yogyakarta II". 
Selain discovery learning, pembelajaran matematika dapat dijadikan sebagai permainan. Salah satu upaya untuk memperkuat konsep pembelajaran discovery learning akan diberikan latihan soal. Latihan soal harus diberikan secara menarik agar siswa tidak jenuh ketika dihadapkan dengan berbagai macam soal. Dienes mengatakan bahwa metode permainan dapat digunakan dalam pembelajaran yang disajikan secara menarik dan mudah dipelajari (Ruseffendi, 1980:134-138). Hal ini dikarenakan belajar sambil bermain akan lebih bermakna dan menumbuhkan semangat siswa dalam proses pembelajaran, dimana siswa akan terlibat secara langsung. Salah satu bentuk permainan yang dapat digunakan untuk menciptakan pembelajaran yang lebih menarik melalui latihan soal adalah metode scramble.

Scramble memungkinkan siswa untuk lebih terlibat secara langsung, dimana guru memberikan beberapa pertanyaan, kemudian siswa mencari jawaban sendiri, dan siswa berani mencoba menyelesaikan latihan soal. Menurut Taylor (Huda, 2014), Scramble merupakan salah satu metode pembelajaran yang dapat meningkatkan konsentrasi dan kecepatan berfikir siswa. Metode ini mengharuskan siswa untuk menggabungkan otak kanan dan otak kiri. Dalam metode ini, mereka tidak hanya diminta untuk menjawab soal, tetapi juga menerka dengan cepat jawaban soal yang sudah tersedia, namun masih dalam kondisi acak. Ketetapan dan kecepatan berpikir dalam menjawab soal menjadi salah satu kunci permainan metode Scramble. Skor siswa / kelompok ditentukan oleh seberapa banyak soal yang benar dan seberapa cepat soal-soal tersebut dikerjakan.

Penelitian yang telah dilakukan oleh Belandina (2011:2), menginformasikan bahwa metode scramble dapat meningkatkan hasil belajar siswa. Sejalan dengan hal tersebut, penelitian ini mengacu pada penelitian yang dilakukan oleh Akhdinirwanto, dkk (2012) tentang penggunaan model pembelajaran scramble untuk peningkatan motivasi belajar IPA (fisika) pada siswa SMP Negeri 16 purworejo tahun pelajaran 2011/2012. Peningkatan motivasi belajar ini berpengaruh terhadap peningkatan hasil belajar.

Berdasarkan permasalahan hasil belajar dan adanya teori yang menyatakan bahwa keaktifan belajar sebagai salah satu kunci keberhasilan dalam pencapaian tujuan pembelajaran, serta adanya hasil penelitian yang menyatakan model discovery learning dan scramble berpengaruh terhadap terhadap hasil belajar, menjadi dasar dilakukan penelitian tentang pengaruh discovery learning dengan scramble terhadap hasil belajar matematika siswa. Selain itu, adanya penelitian yang menyatakan model discovery learning dan scramble tidak berpengaruh terhadap keaktifan belajar siswa. Penelitian ini dilakukan dalam pembelajaran matematika bagi siswa kelas X SMA N 1 Klego Kabupaten Boyolali. Oleh karena itu, penelitian ini diberi judul "Pengaruh penggunaan Discovery learning dengan scramble terhadap Keaktifan Belajar dan Hasil Belajar Matematika Siswa Kelas X SMA N 1 Klego Kabupaten Boyolali Semester II Tahun Pelajaran 2020 / 2021”.

Tujuan dari penelitian ini adalah untuk mengetahui ada tidaknya pengaruh penggunaan discovery learning dengan scramble terhadap keaktifan belajar bagi siswa kelas X SMA N 1 Klego, Kabupaten Boyolali Semester II Tahun Pelajaran 2020/2021, dan mengetahui ada tidak adanya pengaruh penggunaan discovery learning dengan scramble terhadap hasil belajar matematika bagi siswa kelas X SMA N 1 Klego, Kabupaten Boyolali Semester II Tahun Pelajaran 2020/2021 Penelitian ini diharapkan dapat memberikan pengetahuan dan pengalaman tentang penggunaan discovery learning dengan Scramble pada mata pelajaran matematika sebagai upaya mencapai mutu pembelajaran yang optimal.

\section{METODE PENELITIAN}

Penelitian yang digunakan adalah penelitian eksperimen. Penelitian eksperimen dapat diartikan sebagai metode penelitian yang digunakan untuk mencari pengaruh perlakuan tertentu terhadap variabel lain dalam kondisi yang terkendalikan (Sugiyono, 2012:72). Jenis penelitian ini adalah penelitian eksperimen semu (quasi experiment). Suatu penelitian eksperimen disebut eksperimen semu jika tidak memungkinkan bagi peneliti untuk memanipulasi dan atau mengendalikan semua variabel yang relevan (Budiyono, 2003:83). 
Penelitian ini dilaksanakan di SMA N 1 Klego Kabupaten Boyolali Semester II Tahun Pelajaran 2020/2021. Populasi dalam penelitian ini adalah seluruh siswa kelas X SMA N 1 Klego yang berjumlah 203 siswa yang terbagi atas 6 kelas. Teknik pengambilan sampel dilakukan dengan cluster random sampling dan diperoleh kelas X IPS 1 sebagai kelas eksperimen yang berjumlah 36 siswa dan kelas X IPS 2 sebagai kelas kontrol berjumlah 33 siswa. Kelas eksperimen diberi perlakuan discovery learning dengan scramble, sedangkan kelas kontrol dengan pembelajaran satu arah. Variabel bebas dalam penelitian ini adalah model pembelajaran discovery learning dengan scramble. Adapun variabel terikat dalam penelitian ini terdiri dari dua yaitu keaktifan belajar dan hasil belajar.

Desain penelitian yang digunakan dalam penelitian ini adalah the randomized kontrol group pretest posttest design. Teknik pengumpulan data menggunakan metode angket, metode dokumentasi, metode observasi, dan metode tes. Metode angket digunakan untuk mengukur keaktifan belajar siswa sebelum diberi perlakuan dan setelah adanya perlakuan. Angket terdiri dari 25 pernyataan, masing-masing pernyataan memiliki skor tertinggi adalah 4 dan skor terendah adalah 1 . Metode dokumentasi digunakan untuk memperoleh nilai UTS yang dijadikan sebagai nilai pretest untuk mengetahui kemampuan awal sebelum diberi suatu perlakuan. Metode observasi digunakan untuk mengamati keaktifan belajar siswa selama mengikuti proses pembelajaran baik di kelas eksperimen maupun di kelas kontrol. Metode tes dilakukan untuk mengetahui hasil belajar siswa setelah mendapatkan perlakuan, tes yang diberikan berupa posttest, soal posttest berupa soal uraian yang terdiri dari 8 butir soal pada materi lingkaran.

Sebelum instrumen angket dan posttest hasil belajar dilakukan uji instrumen terlebih dahulu. Uji instrumen angket terdiri dari uji validasi expert judgement, uji validasi butir soal dan uji reliabilitas. Instrumen posttest hasil belajar dilakukan uji validitas dengan expert judgement. Penelitian ini memiliki 2 hipotesis. Hipotesis yang pertama adalah terdapat pengaruh penggunaan discovery learning dengan scramble terhadap keaktifan belajar siswa kelas X SMA N 1 Klego Kabupaten Boyolali. Adapun hipotesis yang kedua adalah terdapat pengaruh penggunaan discovery learning dengan scramble terhadap hasil belajar matematika bagi siswa kelas X SMA N 1 Klego Kabupaten Boyolali.

Analisis data terdiri dari dua jenis yaitu, analisis deskriptif dan analisis inferensial. Analisis deskriptif berfungsi untuk mendeskriptifkan atau memberi gambaran terhadap objek yang diteliti melalui data sampel atau populasi sebagaimana adanya, tanpa bermaksud membuat kesimpulan yang berlaku untuk umum (Sugiyono, 2012: 207- 208). Data yang diperoleh dari angket dan hasil belajar pada kelas kontrol maupun kelas eksperimen dilakukan pengujian deskriptif, pengujian tersebut digunakan untuk mengetahui hasil analisis deskripsi data skor minimum, maksimum, rata-rata, dan standar deviasi dari kedua kelas tersebut. Sedangkan analisis inferensial digunakan untuk menganalisis data sampel, dan hasilnya akan digeneralisasikan (diinferensikan) untuk populasi dimana sampel diambil. Selanjutnya uji hipotesis dengan menggunakan uji normalitas sebagai uji prasyarat, bila uji normalitas terpenuhi maka menggunakan statistik parametrik yaitu uji independent sampel t-test sebagai uji beda rerata. Terpenuhinya uji homogenitas menggunakan uji independent sampel t-test jenis equal variances assumed, akan tetapi bila uji homogenitas tidak terpenuhi maka menggunakan uji independent sampel t-test jenis equal variances not assumed. Namun, jika uji normalitas tidak terpenuhi akan dilakukan uji kesamaan dua rerata (t- test) dengan uji non parametrik menggunakan uji Mann-Whitney $U$. Keseluruhan uji ini dilakukan pada taraf signifikansi 5\% dengan alat bantu perhitungan sofware SPSS 20.00.

\section{HASIL PENELITIAN}

\section{Keaktifan belajar sebelum perlakuan.}


Data keaktifan siswa diperoleh dari 36 siswa kelas eksperimen dan 33 siswa kelas kontrol berdasarkan skor pengisian angket keaktifan belajar sebelum adanya perlakuan. Deskripsi data tersebut dapat dilihat pada Tabel 1. Data pada Tabel 1 bahwa skor minimum kelas eksperimen dan kelas kontrol sama. Skor maksimum kelas eksperimen lebih rendah dari kelas kontrol, yaitu berbeda 4 poin. Rata-rata keaktifan belajar pada kelas eksperimen lebih rendah dari kelas kontrol sebesar 1,95. Kemampuan awal siswa pada kelas kontrol lebih beragam dari kelas eksperimen. Hal ini ditunjukkan dari standar deviasi kelas kontrol lebih besar dari pada kelas eksperimen. Kategori keaktifan belajar siswa pada kondisi awal kedua kelompok sampel dapat dilihat pada Tabel 2.

Tabel 1 Data Statistik Deskriptif Pre Test Angket Keaktifan Belajar

\begin{tabular}{|l|r|r|r|r|r|}
\hline & $\mathrm{N}$ & Minimum & Maximum & Mean & $\begin{array}{c}\text { Std. } \\
\text { Deviation }\end{array}$ \\
\hline Eksperimen & 36 & 60 & 73 & 65,75 & 3,988 \\
\hline Kontrol & 33 & 60 & 77 & 67,70 & 4,792 \\
\hline $\begin{array}{l}\text { Valid N } \\
\text { (listwise) }\end{array}$ & 33 & & & & \\
\hline
\end{tabular}

Berdasarkan Tabel 2 terlihat bahwa tidak ada siswa dalam kategori rendah baik pada kelas eksperimen maupun kelas kontrol. Sebagian besar siswa termasuk dalam kategori sedang pada kelas eksperimen sebanyak 30 siswa atau 83\% dari 36 siswa, pada kelas kontrol sebanyak 23 siswa atau 70\% dari 33 siswa. Kategori tinggi pada kelas eksperimen sebanyak 6 siswa atau 17\% dari 36 siswa, pada kelas kontrol sebanyak 10 atau 30\% dari 33 siswa.

Tabel 2. Kategori keaktifan belajar siswa kondisi awal

\begin{tabular}{|c|c|c|c|c|c|}
\hline \multirow{2}{*}{ Interval } & \multirow{2}{*}{ Kategori } & \multicolumn{2}{|c|}{ Kelas Eksperimen } & \multicolumn{2}{|c|}{ Kelas Kontrol } \\
\cline { 3 - 6 } & Jumlah & Persentase & Jumlah & Persentase \\
\hline $\begin{array}{c}23 \leq \mathrm{X}< \\
47\end{array}$ & Rendah & 0 & $0 \%$ & 0 & $0 \%$ \\
\hline $\begin{array}{c}47 \leq \mathrm{X} \\
<71\end{array}$ & Sedang & 30 & $83 \%$ & 23 & $70 \%$ \\
\hline $\begin{array}{c}71 \leq \mathrm{X}< \\
95\end{array}$ & Tinggi & 6 & $17 \%$ & 10 & $30 \%$ \\
\hline
\end{tabular}

siswa sebelum perlakuan.

belajar

Data pretest digunakan untuk mengetahui kondisi awal hasil belajar, 36 siswa kelas eksperimen dan 33 siswa kelas kontrol adalah data nilai Ulangan Tengah Semester. Deskripsi data tersebut dapat dilihat pada Tabel 3. 
Tabel 3. Deskripsi Hasil Belajar Matematika Pada Kondisi Awal

\begin{tabular}{|c|c|c|c|c|c|}
\hline & $\mathrm{N}$ & $\begin{array}{c}\text { Minimu } \\
\mathrm{m}\end{array}$ & Maximum & Mean & $\begin{array}{c}\text { Std. } \\
\text { Deviation } \\
\end{array}$ \\
\hline Eksperimen & 36 & 52 & 87 & 69,11 & 7,570 \\
\hline Kontrol & 33 & 54 & 89 & 69,06 & 7,730 \\
\hline $\begin{array}{l}\text { Valid N } \\
\text { (listwise) }\end{array}$ & 33 & & & & \\
\hline
\end{tabular}

Data pada Tabel 3 dapat dilihat bahwa skor minimum, maksimum kelas eksperimen dan kelas kontrol tidak jauh berbeda, masing-masing hanya berbeda 2 poin. Selain itu, rata-rata hasil belajar dari kedua kelaspun hampir sama yaitu 69 dengan standar deviasinya juga hampir sama yaitu berkisaran 7. Dimana kemampuan siswa pada kelas kontrol lebih beragam dari kelas eksperimen. Kategori kemampuan awal hasil belajar kelas eksperimen dan kelas kontrol dapat dilihat pada Tabel 4.

Tabel 4. Kategori Hasil Belajar Kondisi awal

\begin{tabular}{|l|l|r|r|r|r|}
\hline \multirow{2}{*}{ Interval } & \multirow{2}{*}{ Kategori } & \multicolumn{2}{c|}{ Kelas Eksperimen } & \multicolumn{2}{c|}{ Kelas Kontrol } \\
\cline { 3 - 6 } & & Jumlah & Persentase & Jumlah & Persentase \\
\hline $\begin{array}{l}52,0 \leq \mathrm{x}< \\
64,4\end{array}$ & \multirow{2}{*}{ Rendah } & 10 & $28 \%$ & 9 & $27 \%$ \\
\hline $\begin{array}{l}64,4 \leq \mathrm{x}< \\
76,8\end{array}$ & Sedang & 21 & $58 \%$ & 19 & $58 \%$ \\
\hline $\begin{array}{l}76,8 \leq \mathrm{x}< \\
89,2\end{array}$ & Tinggi & 5 & $14 \%$ & 5 & $15 \%$ \\
\hline
\end{tabular}

Berdasarkan Tabel 4 terlihat bahwa siswa yang termasuk dalam kategori rendah pada kelas eksperimen sebanyak 10 siswa atau 28\% dari 36 siswa, pada kelas kontrol sebanyak 9 siswa atau $27 \%$ dari 33 siswa. Kategori sedang pada kelas eksperimen sebanyak 21 siswa atau 58\% dari 36 siswa, pada kelas kontrol sebanyak 19 siswa atau 58\% dari 33 siswa. Kategori tinggi pada kelas eksperimen sebanyak 5 siswa atau 14\% dari 36 siswa, pada kelas kontrol sebanyak 5 siswa atau $15 \%$ dari 33 siswa.

\section{Uji keseimbangan kondisi awal kedua kelompok sampel}

1) Uji normalitas

Hasil uji normalitas pretest pada Tabel 5 menunjukkan bahwa nilai signifikansi keaktifan belajar dari kelas eksperimen maupun kelas kontrol adalah 0,058 dan 0,200, kedua kelas memiliki nilai signifikansi lebih dari 0,05. Oleh karena itu, dapat disimpulkan bahwa data pretest keaktifan belajar dari kedua kelas berasal dari populasi yang berdistribusi normal. Selain itu, data pretest hasil belajar menunjukkan nilai signifikansi kelas eksperimen dan kelas kontrol sebesar 0,200, nilai signifikansi tersebut lebih dari 0,05. Oleh karena itu, data pretest hasil belajar kedua sampel berasal dari populasi yang berdistribusi normal.

Tabel 5. Hasil uji Normalitas Data pretest

\begin{tabular}{|l|l|l|l|l|}
\hline \multirow{2}{*}{ Kelas } & \multicolumn{3}{|c|}{ Kolmogorov Smirnov } \\
\cline { 3 - 5 } & Statistic & Df & Sig \\
\hline
\end{tabular}




\begin{tabular}{|c|c|c|c|c|}
\hline \multirow{2}{*}{$\begin{array}{c}\text { Keaktifan } \\
\text { belajar }\end{array}$} & Eksperimen & 0,144 & 36 & 0,058 \\
\cline { 2 - 5 } & Kontrol & 0,109 & 33 & 0,200 \\
\hline \multirow{2}{*}{$\begin{array}{c}\text { Hasil } \\
\text { belajar }\end{array}$} & Eksperimen & 0,115 & 36 & 0,200 \\
\cline { 2 - 5 } & Kontrol & 0,098 & 33 & 0,200 \\
\hline
\end{tabular}

2) Uji homogenitas dan uji independent sample t test

Terpenuhi uji normalitas maka menggunakan uji independent sample $t$ test sebagai uji beda rerata. Hasil uji independent sample t test dapat dilihat pada Tabel 6.

Tabel 6. Hasil uji independent sample t test pretest.

\begin{tabular}{|c|c|c|c|c|c|c|}
\hline & \multicolumn{2}{|c|}{$\begin{array}{c}\text { Levene's } \\
\text { Test for } \\
\text { Equality of } \\
\text { Variances }\end{array}$} & \multicolumn{3}{|c|}{$\begin{array}{l}\text { t-test for Equality of } \\
\text { Means }\end{array}$} \\
\hline & & $\mathrm{F}$ & Sig & $\mathrm{T}$ & df & $\begin{array}{l}\text { Sig. (2- } \\
\text { tailed) }\end{array}$ \\
\hline \multirow{2}{*}{$\begin{array}{l}\text { Keaktifa } \\
\mathrm{n} \text { belajar }\end{array}$} & Equal variances assumed & $\begin{array}{c}0,35 \\
1\end{array}$ & $\begin{array}{c}0,55 \\
6\end{array}$ & $-1,840$ & 67 & 0,070 \\
\hline & $\begin{array}{l}\text { Equal variances not } \\
\text { assumed }\end{array}$ & & & $-1,825$ & $\begin{array}{c}62,49 \\
8\end{array}$ & 0,073 \\
\hline \multirow{2}{*}{$\begin{array}{l}\text { Hasil } \\
\text { belajar }\end{array}$} & Equal variances assumed & $\begin{array}{c}0,05 \\
5\end{array}$ & $\begin{array}{c}0,81 \\
6\end{array}$ & 0,027 & 67 & 0,978 \\
\hline & $\begin{array}{c}\text { Equal variances not } \\
\text { assumed }\end{array}$ & & & 0,027 & $\begin{array}{c}66,21 \\
1\end{array}$ & 0,978 \\
\hline
\end{tabular}

Data pada Tabel 6 terlihat bahwa nilai signifikansi dari uji homogenitas keaktifan belajar adalah 0,556 (lebih dari 0,05). Hal ini bearti kelompok sampel pada kedua kelas berasal dari populasi yang memiliki variansi yang sama (homogen). Oleh karena itu, uji independent sample $t$ test yang digunakan jenis Equal variances assumed. Hasil ini menunjukkan bahwa nilai signifikansi keaktifan belajar sebesar 0,070 (lebih dari 0,05). Oleh karena itu, dapat disimpulkan bahwa kemampuan awal siswa dari kedua kelas seimbang. Selain itu, hasil uji independent sample t test untuk data hasil belajar adalah 0,816 (lebih dari 0,05). Hal ini bearti kelompok sampel pada kedua kelas berasal dari populasi yang memiliki variansi yang sama (homogen), sehingga uji independent sample t test yang digunakan jenis Equal variances assumed. Hasil ini menunjukkan bahwa nilai signifikansi keaktifan belajar sebesar 0,978 (lebih dari 0,05). Oleh karena itu, dapat disimpulkan bahwa kemampuan awal siswa dari kedua kelas seimbang.

\section{Keaktifan belajar setelah perlakuan.}

Data akhir keaktifan belajar yang diperoleh dari 36 siswa kelas eksperimen dan 33 kelas kontrol digunakan untuk mengetahui keaktifan belajar siswa setelah diberi perlakuan. Deskripsi data tersebut dapat dilihat pada Tabel 7.

Tabel 7. Statistik Deskripsi Hasil Posttest Keaktifan Belajar

\begin{tabular}{|l|c|c|c|c|c|}
\hline & $\mathrm{N}$ & $\begin{array}{c}\text { Minimu } \\
\mathrm{m}\end{array}$ & $\begin{array}{c}\text { Maximu } \\
\mathrm{m}\end{array}$ & Mean & $\begin{array}{c}\text { Std. } \\
\text { Deviatio } \\
\mathrm{n}\end{array}$ \\
\hline Eksperimen & 36 & 70 & 94 & 80,11 & 5,301 \\
\hline
\end{tabular}




\begin{tabular}{|c|c|c|c|c|c|}
$\begin{array}{c}\text { Kontrol } \\
\text { Valid N } \\
\text { (listwise) }\end{array}$ & 33 & 69 & 87 & 76,03 & 5,971 \\
\hline
\end{tabular}

Berdasarkan data pada Tabel 7 terlihat bahwa skor minimum kelas eksperimen dan kelas kontrol tidak jauh berbeda hanya berbeda 1 poin. Skor maksimum kelas eksperimen lebih tinggi dari kelas kontrol yaitu berbeda 7 poin. Rata-rata keaktifan belajar siswa dari kedua kelas sebesar 3,98, dimana rata-rata keaktifan siswa kelas eksperimen lebih baik dari kelas kontrol. Kemampuan siswa pada kelas kontrol lebih beragam daripada kelas eksperimen. Hal ini ditunjukkan dari standar deviasi kelas kontrol lebih besar dari kelas eksperimen. Kategori kemampuan akhir keaktifan belajar antara kelas eksperimen dan kelas kontrol dapat dilihat pada Tabel 8.

Tabel 8. Kategori posttest Skor Keaktifan Belajar Siswa

\begin{tabular}{|c|c|c|c|c|c|}
\hline \multirow{2}{*}{ Interval } & \multirow{2}{*}{ Kategori } & \multicolumn{2}{|c|}{ Kelas Eksperimen } & \multicolumn{2}{c|}{ Kelas Kontrol } \\
\cline { 3 - 6 } & Jumlah & Persentase & Jumlah & Persentase \\
\hline $\begin{array}{c}23 \leq \mathrm{X}< \\
47\end{array}$ & Rendah & 0 & $0 \%$ & 0 & $0 \%$ \\
\hline $\begin{array}{c}47 \leq \mathrm{X} \\
<71\end{array}$ & Sedang & 3 & $8 \%$ & 13 & $39 \%$ \\
\hline $\begin{array}{c}71 \leq \mathrm{X} \\
<95\end{array}$ & Tinggi & 33 & $92 \%$ & 20 & $61 \%$ \\
\hline
\end{tabular}

Berdasarkan Tabel 8 menunjukkan bahwa tidak ada siswa dalam kategori rendah baik pada kelas eksperimen maupun kelas kontrol. Kategori sedang pada kelas eksperimen sebanyak 3 siswa atau 8\% dari 36 siswa, pada kelas kontrol sebanyak 13 siswa atau 39\% dari 33 siswa. Kategori tinggi pada kelas eksperimen sebanyak 33 siswa atau 92\% dari 36 siswa, pada kelas kontrol sebanyak 20 siswa atau $61 \%$ dari 33 siswa. Akan tetapi, keaktifan belajar pada kondisi akhir menunjukkan bahwa kedua kelas berada pada kategori tinggi untuk setiap kelasnya.

\section{Hasil belajar setelah perlakuan.}

Data akhir dari 36 siswa kelas eksperimen dan 33 kelas kontrol adalah data nilai posttest. Deskripsi data tersebut dapat dilihat pada Tabel 9.

Tabel 9. Deskripsi posttest Hasil Belajar Matematika

\begin{tabular}{|c|c|c|c|c|c|}
\hline & $\mathrm{N}$ & Minimum & $\begin{array}{c}\text { Maximu } \\
\mathrm{m}\end{array}$ & Mean & $\begin{array}{c}\text { Std. } \\
\text { Deviation }\end{array}$ \\
\hline $\begin{array}{c}\text { Eksperime } \\
\mathrm{n}\end{array}$ & 36 & 52 & 94 & 69,72 & 7,611 \\
$\begin{array}{c}\text { Kontrol } \\
\text { Valid N } \\
\text { (listwise) }\end{array}$ & 33 & 51 & 80 & 65,39 & 7,810 \\
\hline
\end{tabular}


Berdasarkan data pada Tabel 9 dapat dilihat bahwa skor minimum kelas eksperimen dan kelas kontrol hanya berbeda 1 poin. Skor maksimum kelas eksperimen lebih tinggi dari kelas kontrol yaitu berbeda 6 poin. Rata-rata kelas eksperimen lebih tinggi dibanding kelas kontrol sebesar 4,33. Kemampuan siswa pada kelas kontrol lebih beragam dari pada siswa kelas eksperimen. Hal ini ditunjukkan dari standar deviasi kelas kontrol lebih besar dari kelas eksperimen yaitu berkisaran 7. Kategori kondisi akhir hasil belajar kelas eksperimen dan kelas kontrol dapat dilihat pada Tabel 10.

Tabel 10. Kategori Hasil Belajar posttest

\begin{tabular}{|c|c|c|c|c|c|}
\hline \multirow{2}{*}{ Interval } & \multirow{2}{*}{ Kategori } & \multicolumn{2}{|c|}{ Kelas Eksperimen } & \multicolumn{2}{c|}{ Kelas Kontrol } \\
\cline { 3 - 6 } & Jumlah & Persentase & Jumlah & Persentase \\
\hline $\begin{array}{c}51,00 \leq \mathrm{X}< \\
65,4\end{array}$ & Rendah & 9 & $25 \%$ & 15 & $45 \%$ \\
\hline $\begin{array}{c}65,4 \leq \mathrm{X} \\
<79,8\end{array}$ & Sedang & 25 & $69 \%$ & 17 & $52 \%$ \\
\hline $\begin{array}{c}79,8 \leq \mathrm{X} \\
<94,2\end{array}$ & Tinggi & 2 & $6 \%$ & 1 & $3 \%$ \\
\hline
\end{tabular}

Berdasarkan Tabel 10 menunjukkan bahwa kategori rendah pada kelas eksperimen sebanyak 9 siswa atau 25\% dari 36 siswa, pada kelas kontrol sebanyak 15 siswa atau $45 \%$ dari 33 siswa. Kategori sedang pada kelas eksperimen sebanyak 25 siswa atau 69\% dari 36 siswa, pada kelas kontrol sebanyak 17 siswa atau 52\% dari 33 siswa. Kategori tinggi pada kelas eksperimen sebanyak 2 siswa atau $6 \%$ dari 36 siswa, pada kelas kontrol sebanyak 1 siswa atau $3 \%$ dari 33 siswa.

\section{Uji hipotesis}

1) Uji normalitas

Hasil uji normalitas posttest pada Tabel 11 menunjukkan bahwa nilai signifikansi keaktifan belajar dari kelas eksperimen adalah 0,078 lebih dari 0,05, pada kelas kontrol adalah 0,000 artinya mendekati nol (kurang dari 0,05 ). Karena nilai signifikansi kelas kontrol kurang dari 0,05. Hal ini berarti kedua kelompok sampel tidak berasal dari populasi yang berdistribusi normal, maka akan dilakukan uji kesamaan beda rerata melalui dua pihak menggunakan uji non parametrik yaitu uji Mann Whitney $U$.

Hasil uji normalitas hasil belajar dari kelas eksperimen dan kelas kontrol masingmasing adalah 0,200. Oleh karena itu, disimpulkan bahwa masing-masing data hasil belajar pada kondisi akhir berasal dari populasi yang berdistribusi normal.

Tabel 11. Uji normalitas data posttest

\begin{tabular}{|c|c|c|c|c|}
\hline \multirow{2}{*}{} & \multirow{2}{*}{ Kelas } & \multicolumn{3}{|c|}{ Kolmogorov Smirnov } \\
\cline { 3 - 5 } & & Statistic & Df & Sig. \\
\hline \multirow{2}{*}{$\begin{array}{c}\text { Keaktifan } \\
\text { belajar }\end{array}$} & Eksperimen & 0,139 & 36 & 0,078 \\
\cline { 2 - 5 } & Kontrol & 0,238 & 33 & 0,000 \\
\hline \multirow{2}{*}{\begin{tabular}{c} 
Hasil belajar \\
\cline { 3 - 5 }
\end{tabular}} & Eksperimen & 0,110 & 36 & 0,200 \\
\cline { 2 - 5 } & Kontrol & 0,097 & 33 & 0,200 \\
\hline
\end{tabular}


2) Uji Mann Whitney $U$

Hasil uji Mann Whitney $U$ keaktifan belajar dapat dilihat pada Tabel 12 tampak bahwa nilai signifikansi sebesar 0,010 (kurang dari 0,05). Artinya keaktifan belajar siswa yang diberi perlakuan discovery learning dengan scramble lebih baik dibanding keaktifan belajar siswa pada pembelajaran satu arah. Oleh karena itu, dapat disimpulkan bahwa keaktifan belajar siswa yang diberi perlakuan discovery learning dengan scramble secara signifikansi lebih baik dibanding keaktifan belajar siswa pada pembelajaran satu arah pada siswa kelas X SMA N 1 Klego.

Table 12. Test Statistics ${ }^{\mathrm{a}}$

\begin{tabular}{|l|r|}
\hline & \multicolumn{1}{|c|}{ Nilai } \\
\hline Mann-Whitney U & 380,500 \\
Wilcoxon W & 941,500 \\
Z & $-2,577$ \\
Asymp. Sig. (2- & 0,010 \\
tailed) & \\
\hline
\end{tabular}

3) Uji homogenitas dan a. Grouping Variable: kelas

independent sample $t$ test

Terpenuhinya uji normalitas dari data hasil belajar maka menggunakan uji independent sample t test sebagai uji beda rerata. Hasil uji independent sample t test dapat dilihat pada Tabel 13.

Tabel 13. Hasil uji homogenitas data posttest hasil belajar.

\begin{tabular}{|c|c|c|c|c|c|c|}
\hline \multicolumn{2}{|c|}{} & \multicolumn{2}{|c|}{$\begin{array}{c}\text { Levene's } \\
\text { Test for } \\
\text { Equality of } \\
\text { Variances }\end{array}$} & \multicolumn{3}{|c|}{ t-test for Equality of } \\
Means \\
\cline { 3 - 7 } & F & Sig & T & df & $\begin{array}{c}\text { Sig. } \\
(2- \\
\text { tailed })\end{array}$ \\
\hline $\begin{array}{c}\text { Hasil } \\
\text { belaja } \\
\text { r }\end{array}$ & $\begin{array}{c}\text { Equal variances } \\
\text { assumed }\end{array}$ & $\begin{array}{c}0,85 \\
7\end{array}$ & $\begin{array}{c}0,35 \\
8\end{array}$ & 2,330 & 67 & 0,023 \\
\cline { 2 - 7 } & $\begin{array}{c}\text { Equal variances not } \\
\text { assumed }\end{array}$ & & & 2,328 & 66,138 & 0,023 \\
\hline
\end{tabular}

Hasil uji independent sample t test pada Tabel 13 terlihat bahwa nilai signifikansi dari uji homogenitas hasil belajar adalah 0,358 (lebih dari 0,05). Hal ini berarti kelompok sampel pada kedua kelas berasal dari populasi yang memiliki variansi yang sama (homogen). Oleh karena itu, uji independent sample t test yang digunakan jenis Equal variances assumed. Hasil ini menunjukkan bahwa nilai signifikansi hasil belajar sebesar 0,23 (lebih dari 0,05). $H_{O}$ ditolak dan $H_{a}$ diterima, yang berarti hasil belajar yang diberi perlakuan discovery learning dengan scramble secara signifikansi lebih baik dibanding hasil belajar dengan pembelajaran satu arah. Dengan kata lain terdapat pengaruh penggunaan discovery learning dengan scramble terhadap hasil belajar pada kelas X SMA N 1 Klego Kabupaten Boyolali Semester II Tahun Pelajaran 2020/2021.

\section{Pembahasan}

Penelitian ini bertujuan untuk mengetahui ada tidaknya pengaruh yang signifikan penggunaan discovery learning dengan scramble terhadap keaktifan belajar dan hasil belajar 
matematika bagi siswa kelas X SMA N 1 Klego Kabupaten Boyolali. Penelitian ini menggunakan kelas X IPS 1 sebagai kelas eksperimen dan kelas X IPS 2 sebagai kelas kontrol.

Uji keseimbangan kondisi awal untuk keaktifan belajar dan hasil belajar berturut-turut menghasilkan nilai signifikansi sebesar 0,070 dan 0,978, keduanya lebih dari 0,05. Artinya kedua kelompok sampel dalam kondisi seimbang baik untuk keaktifan belajar maupun hasil belajar. Setelah tahap pelaksanaan pembelajaran di kelas eksperimen dan kelas kontrol, dilakukan posttest. Hasil posttest digunakan untuk mengetahui keaktifan belajar maupun hasil belajar matematika setelah adanya perlakuan selama proses pembelajaran.

Adapun hasil uji hipotesis keaktifan belajar menghasilkan nilai signifikansi sebesar 0,01 dengan rata-rata keaktifan belajar kelas eksperimen 80,11 lebih baik dari kelas kontrol 76,03. Artinya keaktifan belajar siswa yang diberi discovery learning dengan scramble secara signifikansi lebih baik dibanding keaktifan belajar siswa pada pembelajaran satu arah. Oleh karena itu, dapat disimpulkan bahwa keaktifan belajar siswa kelas X SMA N 1 Klegoyang diberi pembelajaran discovery learning dengan scramble lebih baik dibanding keaktifan belajar siswa dengan pembelajaran satu arah bagi siswa kelas X SMA N 1 Klego Kabupaten Boyolali. Hal ini sesuai penelitian Yuliana (2015).

Hasil uji hipotesis hasil belajar menghasilkan nilai signifikansi 0,023 dengan rata-rata hasil belajar kelas eksperimen 69,72 lebih baik daripada kelas kontrol 65,39. Artinya hasil belajar siswa yang diberi discovery learning dengan scramble secara signifikansi lebih baik dibanding hasil belajar pada pembelajaran satu arah bagi siswa kelas X SMA N 1 Klego Kabupaten Boyolali. Oleh karena itu, dapat disimpulkan bahwa hasil belajar siswa kelas X SMA N 1 Klego yang diberi discovery learning dengan scramble lebih baik dibanding hasil belajar siswa dengan pembelajaran satu arah bagi siswa kelas X SMA N 1 Klego Kabupaten Boyolali. Hal ini sesuai penelitian Yuliana (2015) dan penelitian Bambang (2014).

Proses pembelajaran yang menggunakan discovery learning dengan scramble dilakukan pada kelas eksperimen dan model pembelajaran satu arah pada kelas kontrol, pelaksanaan pembelajaran selama 5 kali pertemuan (@5 x 40 menit). Pertemuan I pada materi pengertian segitiga siku-siku, pertemuan II dengan materi perbandingan sisi segitiga siku-siku, perbandingan sisi trigonometri pada segitiga siku-siku, pertemuan III dengan latihan soal dari materi pertemuan II, pertemuan IV dengan materi sudut berelasi dari berbagai kuadran, pertemuan V latihan soal dari pertemuan IV.

Pelaksanaan pembelajaran pada kelas eksperimen dengan discovery learning dimulai pada tahap stimulus. Tahap stimulus yang diberikan guru pada pertemuan I dan II berupa potongan segitiga siku-siku. Tahap stimulus pada pertemuan IV berupa kartu domino untuk latihan soal sudut berelasi. Pada tahap ini siswa terlibat secara langsung, dimana siswa menyebutkan perbandingan sisi trigonometri. Hal ini tidak terjadi pada kelas kontrol dengan pembelajaran satu arah. Pada kelas kontrol, siswa menyebutkan perbandingan sisi trigonometri yang berada di ruang kelasnya dan guru menggambar segitiga siku-siku yang akan diikuti oleh siswa.

Sebelum tahap yang kedua, guru membentuk 12 kelompok besar, masing-masing kelompok terdiri dari 3 anggota. Selanjutnya tahap problem statement, pada tahap ini untuk pertemuan I, II dan IV siswa diberi masalah yaitu berupa LKS. Guru meminta siswa untuk membaca petunjuk atau langkah-langkah sebelum mulai mengerjakan. LKS ini berisi tentang pengajuan masalah berupa langkah-langkah mengerjakan dimana siswa diminta untuk membuktikan suatu konsep dengan cara mengikuti langkah-langkah yang sudah tersedia. Selanjutnya tahap data collection dan data processing, pada tahap ini siswa melakukan aktivitas berdasarkan petunjuk untuk mendapatkan suatu konsep atau rumus. Siswa mengisi bagian kolom atau tabel yang masih kosong, siswa diminta untuk mengerjakan secara runtut, tidak boleh ada yang terlewatkan. Hal ini tidak seperti yang dilakukan pada kelas kontrol, pada kelas kontrol guru menuliskan rumus yang sudah ada, kemudian guru mengajak siswa untuk membuktikan rumus dengan cara, siswa menyebutkan langkah-langkah saja, kemudian 
guru menuliskan jawaban siswa di papan tulis, dengan proses pembelajaran seperti ini ada beberapa siswa saja yang aktif dalam pembelajaran.

Pada tahap verification, siswa memulai menemukan perbandingan sisi trigonometri pada masing-masing kegiatan sesuai perintah dari tiap kelompoknya. Masing-masing kelompok mencoba membuktikan berdasarkan hasil dari data processing yang sudah terkumpulkan. Selanjutnya tahap generalization, pada tahap ini guru menunjuk beberapa kelompok untuk mempresentasikan hasil penemuan rumus tersebut, guru menyimpulkan hasil penemuan dari masing-masing kelompok. Diakhir pembelajaran siswa diberi latihan soal, bagi kelompok yang mampu menjawab, akan diberi poin keaktifan. Hal ini tidak seperti pada kelas kontrol, pada kelas kontrol diakhir pembelajaran, siswa diberi kesempatan untuk bertanya, dan diminta untuk mengerjakan latihan soal yang sudah dituliskan di papan tulis, bagi siswa yang mengerjakan di papan tulis akan diberikan poin keaktifan.

Penggunaan scramble diberikan guna memperkuat konsep yang sudah dipelajari ketika pembelajaran discovery learning, dimana siswa sudah mendapatkan beberapa rumus, siswa diminta untuk mengaplikasikannya ke dalam latihan soal. Tahap pertama guru membentuk siswa ke dalam kelompok yang heterogen, masing-masing kelompok terdiri dari 3 anggota. Siswa diberi aturan dalam permainan scramble, guru sudah menyediakan kartu jawaban dan kartu pertanyaan pada meja yang terletak didepan. Siswa akan mengambil kartu jawaban sesuai hasil yang diperoleh setelah mengerjakan, untuk mencegah siswa yang mencontek pekerjaan kelompok lain, maupun hanya menuliskan jawaban saja, pada kartu jawaban disediakan jawaban salah dan jawaban benar.

Selanjutnya, siswa mulai mengerjakan latihan soal tersebut, latihan soal dikerjakan dimana siswa mengerjakannya secara bergiliran yang mempunyai ketentuan searah jarum jam dengan tujuan semua anggota ikut mengerjakan maupun beraktivitas dalam permainan tersebut. Guru memberikan durasi waktu sekitar 30 menit. Bila ada kelompok yang sudah selesai mengerjakan diminta untuk dikumpulkan kepada guru, selanjutnya mengambil kartu pertanyaan yang lainnya, aktivitas permainan akan dilakukan seperti ini sampai waktu habis. Ketika waktu habis siswa diminta untuk mengumpulkan. Untuk mengetahui kelompok yang menjawab soal terbanyak, benar dan sesuai akan diadakan refleksi. Pada akhir pembelajaran, guru mengadakan refleksi dari permainan tersebut, guru membahas ulang soal-soal yang ada di kartu pertanyaan. Pada pelaksanaan permainan guru berperan sebagai fasilitator dimana guru mengontrol jalannya diskusi serta jalannya permainan, siswa yang aktif mengerjakan latihan soal dan berdiskusi dengan kelompoknya.

Hal ini tidak seperti pada kelas kontrol, kelas kontrol guru membentuk siswa ke dalam kelompok yang terdiri dari 3 anggota untuk masing-masing kelompoknya. Siswa diberi latihan soal dari buku paket yang dibawa oleh siswa. Bagi kelompok yang tidak ikut mengerjakan ditulis pada kertas jawaban tersebut, siswa yang tidak ikut mengerjakan akan diberi cap jempol terbalik. Pada pembelajaran latihan soal guru juga berperan sebagai fasilitator, namun peran siswa hanya mengerjakan latihan soal dengan kelompoknya, siswa juga mengerjakan di papan tulis tanpa guru menunjuk siswa yang mengerjakan, peran siswa pada kelas kontrol tidak seperti pada kelas eksperimen yang aktif melakukan permainan.

Kurangnya waktu pertemuan mengakibatkan materi dan pelaksanaan discovery learning dengan scramble belum maksimal. Oleh karena kurangnya latihan soal memungkinkan penanaman konsep yang sudah diperoleh kurang maksimal, kurang alokasi waktu yang dibutuhkan dan bila menggunakan pembelajaran discovery learning pada kelas yang terlalu besar, maka penggelolaan kelas kurang maksimal.

Banyaknya siswa menyebabkan guru tidak dapat memperhatikan siswa satu per satu. Guru juga mengalami kesusahan dalam mengontrol jalannya diskusi pada pelaksanaan model discovery learning misalnya pada pertemuan I, kurang efisien dalam pembagian kelompok, suasana kelas masih gaduh saat pembagian kelompok, guru kurang efektif dalam mengontrol jalannya diskusi, kurang tepat dalam manajemen waktu. 
Pada pertemuan II dan seterusnya hal itu sudah berkurang, misalnya pembagian kelompok sudah baik, ada beberapa kelompok yang memperhatikan penjelasan sebelum siswa diminta untuk mengerjakan menemukan rumus atau konsep, walaupun suasana kelas mengalami kegaduhan akan tetapi sudah berkurang dengan adanya poin keaktifan.

Pada pelaksanaan permainan scramble, pada pertemuan III, ada kendala yang dihadapi guru misalnya, alur permainan yang sudah direncanakan tidak sesuai, hal ini dikarenakan kurangnya pengkondisian selama permainan, banyak siswa yang bertanya dalam mengerjakan soal, bila ada kelompok yang sudah selesai mengerjakan 1 soal, kelompok tersebut menganggu kelompok yang lain. Untuk mengatasi hal tersebut guru mengumumkan kepada siswa bila akan bertanya harap bergiliran, dan bila sudah mengambil kartu pertanyaan tidak boleh ada yang ditukarkan, untuk anggota kelompok yang membuat gaduh akan mendapatkan diskualifikasi serta akan mendapatkan 1 peringatan, bila sudah mendapatkan peringatan yang ketiga kelompok yang bersangkutan tidak boleh mengikuti permainan kembali. Pada pertemuan $\mathrm{V}$ siswa sudah terbiasa maksud pelaksanaan permainan tersebut, siswa mulai giat dalam mengerjakan, akan tetapi kegaduhan di dalam kelas masih saja ada.

Berdasarkan hasil penelitian, ditemukan beberapa siswa yang memiliki keaktifan belajar tinggi namun hasil belajar matematikanya sedang karena tingkat keaktifan belajar yang tinggi belum tentu diimbangi dengan penguasaan materi yang baik. Pada saat diskusi kelompok, siswa berani mempresentasikan hasil diskusi, namun dalam mengerjakan soal posttest, siswa kurang menguasai materi sehingga hasil belajar siswa rendah.

Adapun keaktifan belajar yang sedang, namun hasil belajar matematikanya tinggi. Keaktifan belajar yang rendah menjadi keaktifan sedang, akan tetapi hasil belajar matematikanya tinggi adapula keaktifan belajar yang tinggi diimbagi dengan penguasaan materi yang baik akan memberikan hasil belajar yang optimal. Hal ini terbukti dari keberanian siswa dalam mengemukakan pendapat ketika berdiskusi, mengerjakan soal posttest dengan tenang. Dengan demikian dapat simpulkan bahwa penggunaan model pembelajaran yang efektif dengan melibatkan siswa di dalam proses pembelajaran dapat memberikan hasil belajar yang diharapkan, (Rusman, 2013:111). Hal ini didukung oleh hasil penelitian Yuliana (2015) pada mata pelajaran matematika bahwa terdapat perbedaan yang signifikansi antara keaktifan belajar dan hasil belajar pada siswa SMP, adapun hasil penelitian Akhdinirwanto, dkk (2012) pada mata pelajaran IPA khususnya fisika bahwa terdapat perbedaan yang signifikansi penggunaan scramble terhadap hasil belajar siswa SMP.

\section{KESIMPULAN}

Berdasarkan hasil penelitian dan pembahasan maka kesimpulan dari penelitian ini adalah sebagai berikut.

1. Terdapat pengaruh penggunaan model Discovery Learning dengan Scramble terhadap keaktifan belajar siswa kelas X SMA N 1 Klego Kabupaten Boyolali Semester II Tahun Pelajaran 2020/2021.

2. Terdapat pengaruh penggunaan model Discovery Learning dengan Scramble terhadap hasil belajar matematika siswa kelas X SMA N 1 Klego Kabupaten Boyolali Semester II Tahun Pelajaran 2020/2021.

\section{DAFTAR PUSTAKA}

Arinawati, Eni. (2014). Pengaruh model pembelajaran discovery learning terhadap hasil belajar matematika ditinjau dari motivasi belajar. Jurnal Didakti Dwija Indria(solo).Vol 2 No. 8 Tahun 2014. Akses pada tanggal 5 April 2016 pukul 20.00 WIB http://jurnal.fkip.uns.ac.id/index.php/pgsdsolo/article/view/3634/2583

Baharudin. (2010). Teori belajar dan pembelajaran. Yogyakarta: Ar Ruz Media

Belandina, Febri. (2011). Pengaruh Pembelajaran Kooperatif Tipe Scramble Terhadap Hasil

Belajar Kewarganegaraan. Skripsi. Bandar Lampung: Universitas Lampung.

Budiningsih, Asri. (2005). Belajar dan pembelajaran. Jakarta : Rineka Cipta

Budiyono. (2003). Metodologi penelitian pendidikan. Surakarta: UNS Press 
Depdiknas. (2006). Kurikulum Mata Pelajaran Matematika SMP. Jakarta: Depdiknas.

Gulo, W. (2004). Strategi Belajar Mengajar. Jakarta: Grasindo

Hamalik, O. (2010). Perencanaan Pengajaran (Berdasarkan Pendekatan Sistem). Jakarta: Bumi Aksara

Huda, Miftahul. (2014). Model-model Pengajaran dan Pemnelajaran. Yogyakarta: Pustaka Belajar

Hudojo, Herman. (2013). Pengembangan kurikulum dan pembelajaran matematika. Malang: IMSTEP JICA FMIPA UM

Nasution, S. (2006). Berbagai Pendekatan Dalam Proses Belajar Mengajar. Jakarta: Rineka Cipta.

Rakhmawati,Tri. Fatmaryanti , Siska Desy. Akhdinirwanto, Wakhid. (2012). Penggunaan Model Pembelajaran Scramble untuk Peningkatan Motivasi Belajar IPA (Fisika) pada Siswa SMP Negeri 16 Purworejo Tahun Pelajaran 2011/2012. Radiasi.Vol.1. No.1. Tri Rakhmawati. Akses pada tanggal 7 Juni 2015 pukul 10.00 WIB. http://download.portalgaruda.org/article.php?article=9385\&val=614

Rosila, Fattah, I. (2015). Pengaruh Model Discovery Learning dengan Scramble Metode Praktikum pada Materi Ekosistem terhadap Keaktifan dan Hasil Belajar Siswa Kelas X MAN Yogyakarta II. Skripsi. Yogyakarta: FKIP UIN

Ruseffendi. (1980). Pengajaran Matematika Modern. Bandung: Tarsito

Rusman. (2013). Model-model pembelajaran. Jakarta: Rajawali Pers

Sari, Pika Purnama. (2014). Pengembangan Lembar Kerja Siswa Berbasis Penemuan Terbimbing Pada Materi Lingkaran Kelas VIII Di SMP Negeri 4 Kota Bengkulu. Skripsi. Bengkulu: FKIP Universitas Bengkulu

Slameto. (2010). Belajar dan Faktor-faktor yang Mempengaruhinya . Jakarta: Rineka Cipta

Sugiyono. (2012). Statistika untuk penelitian. Bandung: Alfabeta

Supriyanto, Bambang. (2014). Penerapan Discovery Learning Untuk Meningkatkan Hasil Belajar Siswa Kelas VI B Mata Pelajaran Matematika Pokok Bahasan Keliling dan Luas Lingkaran Di SDN Tanggul Wetan 02 Kecamatan Tanggul Kabupaten Jember. Pancaran, Vol. 3, No. 2, hal 165-174.

Akses pada tanggal 1 April 2016 pukul 19.00 WIB.

http://jurnal.unej.ac.id/index.php/pancaran/article/view/753

Yuliana. (2015). Eksperimentasi Pembelajaran Matematika Melalui Strategi Problem Based Learning Dengan Discovery Learning Ditinjau Dari Keaktifan Siswa Terhadap Hasil Belajar Siswa Kelas VIII Semester Genap SMP N 2 Kartosura Tahun Ajaran 2014/2015. Naskah publikasi. Surakarta: FKIP UMS 